
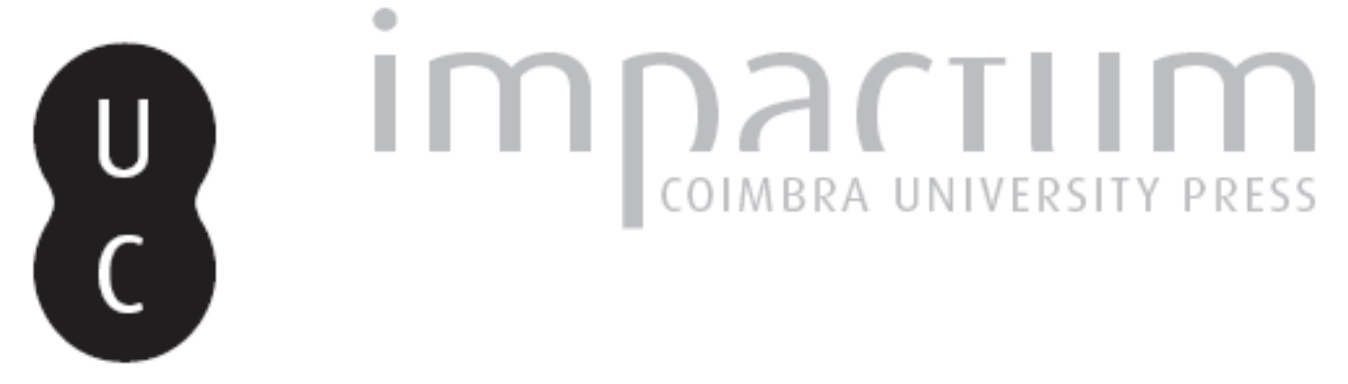

\title{
Dramatic devices and philosophical content in Plato's Symposium
}

\section{Autor(es): O'Brien, Carl}

Publicado por: Annablume Clássica; Imprensa da Universidade de Coimbra

URL persistente:

URI:http://hdl.handle.net/10316.2/24307

DOI:

DOI:http://dx.doi.org/10.14195/1984-249X_9_7

Accessed : $\quad$ 26-Apr-2023 14:46:35

A navegação consulta e descarregamento dos títulos inseridos nas Bibliotecas Digitais UC Digitalis, UC Pombalina e UC Impactum, pressupõem a aceitação plena e sem reservas dos Termos e Condições de Uso destas Bibliotecas Digitais, disponíveis em https://digitalis.uc.pt/pt-pt/termos.

Conforme exposto nos referidos Termos e Condições de Uso, o descarregamento de títulos de acesso restrito requer uma licença válida de autorização devendo o utilizador aceder ao(s) documento(s) a partir de um endereço de IP da instituição detentora da supramencionada licença.

Ao utilizador é apenas permitido o descarregamento para uso pessoal, pelo que o emprego do(s) título(s) descarregado(s) para outro fim, designadamente comercial, carece de autorização do respetivo autor ou editor da obra.

Na medida em que todas as obras da UC Digitalis se encontram protegidas pelo Código do Direito de Autor e Direitos Conexos e demais legislação aplicável, toda a cópia, parcial ou total, deste documento, nos casos em que é legalmente admitida, deverá conter ou fazer-se acompanhar por este aviso.

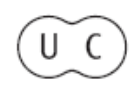




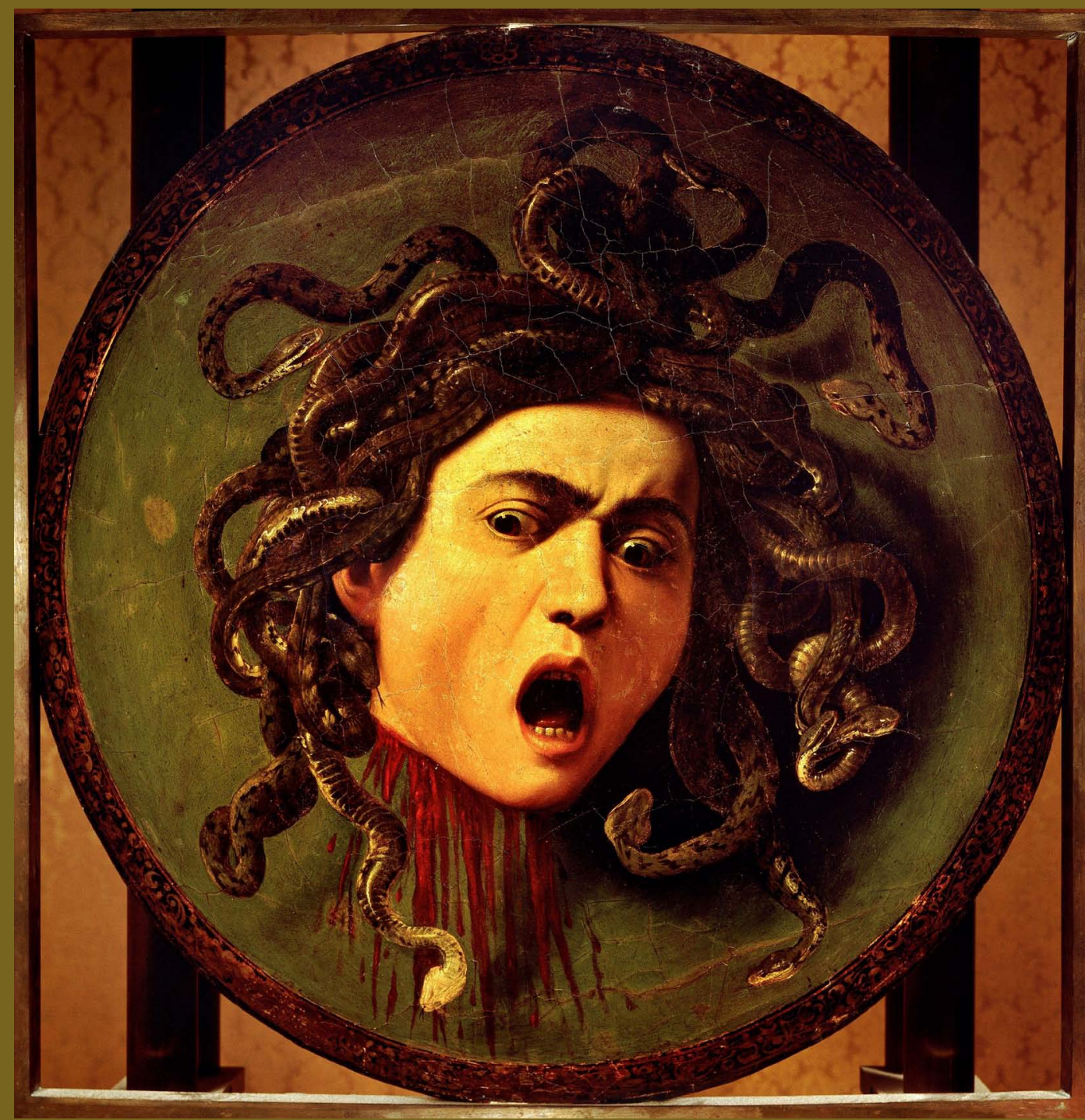

\section{R E V I S T A}
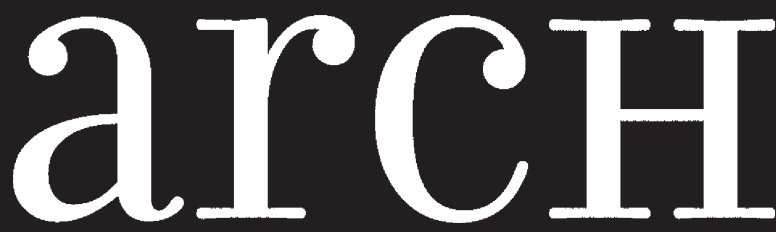
AS ORIGENS DO PENSAMENTO OCIDENTAL

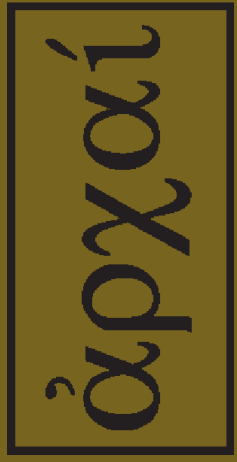

ARCHAI JOURNAL: ON THE ORIGINS OF WESTERN THOUGHT
arcHaI

arementam

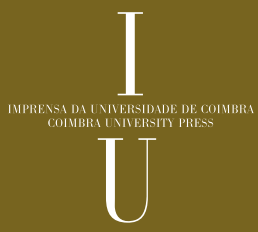

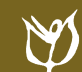

NNN 


\section{DRAMATIC DEVICES AND PHILOSOPHICAL CONTENT IN PLATO'S SYMPOSIUM}

0' BRIEN, C. (2012). “Dramatic devices and philosophical content in Plato's Symposium". Archai n. 9 , jul-dez 2012, pp. 73-84.

RESUMO: 0 Banquete de Platão serve-se de recursos dramáticos diversos, tais como a história-moldura, a organização dos discursos e o ensino de Diotima enquanto meios de orientação do leitor pela mensagem filosófica subjacente, a qual inclui um exame do sistema socrático de educação. Os discípulos de Sócrates demonstram notável entusiasmo pela filosofia, mas parecem incapazes de distinguir o amor por Sócrates do amor pela sabedoria. Agatão ocupa posição de destaque: devido a um trocadilho com o seu nome, a jornada do jantar em sua casa se tornará na ascensão em direção ao Bem. Além disso, ele representa a educação sofística e poética, assim como cada um dos oradores representa algum tipo particular de conhecimento, o que implica que não se deveria simplesmente impingir pedantismo a Eurixímaco, ou tomar o discurso de Aristófanes enquanto um interlúdio cômico. Eles formam, antes, uma complexa rede intertextual. Alcibiades exibe as fraquezas de um homem inábil ou relutante em seguir a totalidade do ensino socrático. Sua solicitação de ser conduzido por Agatão simboliza a incapacidade de encontrar o próprio caminho do Bem, ao passo que a interrupção da ordem bem organizada do banquete pelos boêmios lembra a atitude dos tiranos e de outros homens hostis à filosofia. Apesar dessa crítica aos estudantes de Sócrates, o Banquete finaliza com uma nota positiva. As ações finais de Sócrates ocupam-se das outras pessoas - uma crítica implícita a quem sustenta que a filosofia subverte os laços sociais.

PALAVRAS-CHAVE: Banquete - Sócrates - educação - Bem
* National University of Ireland, Maynooth. My deepest thanks to Prof. John Dillon (Trinity College, Dublin) for his advice and comments on this article and indeed for first introducing me to the Symposium as an undergraduate. I am extremely grateful to Prof. Gabriele Cornelli and Prof. Anastácio Borges de Araújo Junior for the invitation to speak at the conference in Recife, as well as to all of the participants for their responses to this paper, especially to Prof. Francisco Gonzalez (University of Ottawa) for drawing my attention to some of the more positive aspects of Agathon's speech.

\section{Carl O'Brien *}

\section{Introduction}

Plato's fondness for dramatic devices, whether this refers to framing stories, the use of myth or the employment of oracular utterances and divine signs, is well-known. It has also been frequently observed that there is a link between such literary artifices and the philosophical content which he seeks to deliver. The Symposium is a particularly good example of this structure in action, to such an extent that it could accurately be described by Mikhail Bakhtin as the first novel in history. He was not alone: Friedrich Schegel referred to the Socratic dialogues in general as 'the novels of their time'. The Symposium merits this distinction, not because it is the first example of literature to employ such dramatic devices, but rather because it is clear that the author is using such devices as a means of conveying an underlying meaning and conditioning the reader's response. The dramatic elements include the framing story, the arrangement of the speeches, Aristophanes' hiccups, which disrupts their order, the lesson of Diotima, which means that the core philosophical content of the dialogue is delivered as a story within a story which has been recounted at third-hand and finally the interruption of Alcibiades, which is followed by an invasion of revellers leading 
ABSTRACT: Plato's Symposium uses dramatical devices, such as the framing story, the arrangement of the speeches or the lesson with Diotima, as a means of guiding the reader to the underlying philosophical message, which includes an examination of the system of Socratic education. Socrates' acolytes display a commendable enthusiasm for philosophy, but seem incapable of distinguishing between love of Socrates and love of wisdom. Agathon occupies a central position: due to punning on his name, the trek to dinner at his house symbolises the ascent to the Good, and he represents sophistic and poetic education, just as all of the other speakers represent a particular kind of expertise, meaning that Eryximachus should not simply be dismissed as a pedant or Aristophanes' speech regarded as a comic interlude. Rather, they form part of a complex intertextual web. Alcibiades displays the shortcomings of a man unable or unwilling to complete the Socratic course of study; his demand to be taken to Agathon symbolises his inability to find his way to the Good, while the interruption of the revellers into the orderly arrangement of the symposium evokes the attitude of tyrannical men and those hostile towards philosophy. Despite this criticism of some of Socrates' students, the Symposium closes on a positive note. Socrates' final actions in the dialogue are other-centred; an implied critique of those who claim that philosophy undermines social ties.

KEY-WORDS: Symposium - Socrates - education - Good

to the collapse of the symposium.

Although an attempt to treat these aspects can have a tendency to adopt a piecemeal approach, and create the impression that the dialogue is merely a series of episodes, this is something which I hope to avoid by treating all these elements as part of an overarching stragegy which Plato adopts to shape and inform our reading of the Symposium. These devices introduce a discordant element into the dialogue, suggesting the failure of the Socratic elenchus for those who abandon its pursuit prematurely and highlighting the difficulties Socrates himself faces as an educator attempting to lead his youthful charges onto a virtuous path. This criticism applies to the other guests at the Symposium; while the initial impression is of a random collection of representatives of Athenian high society, we find that we are dealing with those concerned either with education, or more specifically those we might expect to be capable of providing further information regarding love: the tragic poet (Agathon), the comic poet (Aristophanes), the scientist/physician (Eryximachus), the lover (Pausanias), the beloved (Phaedrus), the young man about town (Alcibiades), each of whom, like the philosopher Socrates himself, fails to provide the sort of enlightenment which we might expect. These discordant notes are struck early on in the dialogue during the course of the elaborate framing story which Plato constructs as a prelude to the philosophical investigation of the dialogue proper. One must, though, follow Jowett's sage advice: 'If it be true that there are more things in the Symposium of Plato than any commentator has dreamed of, it is also true that many things have been imagined which are not really to be found there'. (JOWETT, 1892, p. 524)

\section{The Framing Story}

The framing story is a Beglaubigungsapparat, familiar from other dialogues, which locates the philosophical discussion at a precise time and place, mentions those present at the event and establishes the overall reliability of the account which we are to hear. It happened when Glaucon and Adeimanthus were little, on the occasion of Agathon's first victory. Apollodorus remembers it well as he has recently recounted the whole story to Glaucon. The problem here, as so often in Plato, is that discordant elements remind us that the narrative need not be so accurate. We never learn the name of the companion of Apollodorus who requests the account. We are far removed in both time and space from the event: it happened long ago and Apollodorus himself was not present; he learnt everything from a follower of Socrates, Aristodemus, who was present, and this remoteness makes Apollodorus' claims of accuracy (by having verified certain details with Socrates, Symp. 173A-B) sound hollow. There are several speeches after Phaedrus' which Aristodemus could not remember, implying an imperfect knowledge of the guest list and the seating arrangements. The recitation of the narrative itself might be seen as engaging in philosophy; it takes place during 
the ascent to the city (anîon, Symp.172A2) which evokes Diotima's ladder (epanîn, 211B), just as the descent into the Piraeus at the opening of the Republic evokes the return of the philosopher into the cave after having attained a vision of the Forms (CORRIGAN \& GLAZOV-CORRIGAN, 2004). The secondary movement, the walk to Agathon's house, or the house of the Good also highlights the process of philosophising: as Socrates comments, the good go of their own accord to the banquets of the Good (Symp.174B).

Despite this, it is clear that Socrates' acolytes are inadequate philosophers. Neither Apollodorus nor Aristodemus seem capable of conducting an elenchus themselves, but simply imitate everything which Socrates does. Apollodorus' unnamed companion too seems incapable of practising the level of philosophical examination required to lead a virtuous life:

...in the case of other sorts of talk - especially that of your wealthy money-bag friends - I am not only annoyed myself, but sorry for dear intimates like you, who think you are doing a great deal when you really do nothing at all. From your point of view, I daresay, I seem a hapless creature, and I think your thought is true. I, however, do not think it of you, I know it for sure (Symp. 173C-D). ${ }^{1}$

Just as the Symposium is an account at a distant remove and via two informants, Apollodorus is an inferior version of Socrates:

You are the same as ever, Apollodorus, - always defaming yourself and everyone else! Your view, I take $i t$, is that all men alike are miserable, save Socrates, and that your own plight is the worst. How you may have come by your title of "crazy", I do not know: though, of course, you are always like that in your way of speech - raging against yourself and everybody except Socrates (Symp. 173D).

Apollodorus cannot even remember the second-hand account which he has learnt from Aristodemus, but rather the account which he recently gave to Glaucon. His attempt at philosophy is limited to the mimetic and he is unable to engage with the account which he received, but must simply recount it in order and by rote. Socrates only 'always appears to be saying the same things in the same ways', according to Alcibiades at 221E, but he is like a Silenus, who can be opened up to reveal deeper meaning.

Such emphasis on the accuracy or inaccuracy of the dialogue can be found elsewhere. In the Theaetetus, Euclides cannot remember the philosophical discussion in question, since it happened so long in the past, but the dialogue is actually represented by an account which he made at the time and which will now be read out by a slave. Such frames can be interpreted in two opposite ways as placing emphasis on either the veracity or the fictitiousness of the account. The Theaetetus frame, though, is different from that of the Symposium. Euclides has been involved in a redrafting process, rather than the simple (and, as is amply indicated, imperfect because incomplete) mimesis of Apollodorus. Euclides composes from notes which he took at the time, and composed a draft which he improved by querying Socrates on various details. This is why I feel that the frame of the Symposium cannot be simply dismissed as a typical example of Platonic paideia, but as a pessimistic reading of the limited nature of Socratic-style education, if not completed. As Corrigan and Glazov-Corrigan note 'play and playfulness between many levels of signification is definitely not alien to his style and must be taken into account in order for one to grasp the very tenor of his philosophical thinking. There is no part of the dialogue that is simply non-philosophical.' (2004, p. 42) Socrates provides the stimulus for Apollodorus to arrive at the house of Agathon, the house of the Good, but he must enter there himself; Socrates, it will be remembered, pauses in the porch of a neighbouring house to listen to his daimonion. Even the dinner arrangements hint at the difficulties facing Socrates as an educator, when Agathon at Symp. $175 \mathrm{C}$ requests that Socrates sit beside him, so that he may benefit from his wisdom by contact, forcing Socrates to reply: 'How fine it would be, Agathon... if wisdom were a sort of thing that could flow out of the one of us who is fuller 
into him who is emptier, by our mere contact with each other, as water will flow through wool from the fuller cup into the emptier.'

\section{The Arrangement of the Speeches}

The actual arrangement of the speeches on one level is simply as the result of a random seating order, but is obviously of great importance, as Plato continuously draws attention to it. There are four alterations made to the original order: 1) Agathon is displaced by the arrival of Socrates, 2) Eryximachus must speak earlier on account of Aristophanes' hiccups and 3) Agathon and Socrates are displaced by Alcibiades and 4) finally all of the guests are displaced by the invasion of the revellers. There are a number of means of interpreting the order of the speeches: the five preliminary speeches can all be regarded as on the same level, but inferior to Socrates, or each speech can be regarded as surpassing the speech which preceeds it. I would reject such an interpretation since this would characterise Phaedrus as the weakest speaker, which cannot be the case from a Socratic perspective, since he requests instruction. Additionally, it would mean that Agathon would be the strongest speaker, apart from Socrates, whereas elements of his speech can be viewed as a triumph of style over substance, even though Agathon is a central figure.

Alternative structural attempts focus on grouping the speeches into pairs, based upon perceived similarities. So, for example, Phaedrus' and Agathon's speeches both mention one Eros, while Pausanias' and Eryximachus' mention two. One can also reject the claim that the speeches have any significance on the grounds that Aristophanes' hiccups draw attention to the accidental nature of the arrangement. More recent scholarship tends to propound the notion of an intertextual web: the speeches interrelate to produce a more holistic understanding of the truth which Plato is investigating. In this way, the Symposium becomes a recreation of the ideal mechanism for engaging in philosophical activity and goes from competitive encomiasm to a shared enterprise. My own preference is for the intertexual web interpretation, though I feel that the more significant speeches are from the experts; Eryximachus, Agathon, Aristophanes and Socrates, rather than the laymen, Phaedrus and Pausanias. However, these last two greatly enrich the dialogue, since they, along with Alcibiades, speak abour love from personal experience. The choice of eros as a topic for discussion raises the issue of education, since it becomes apparent that the lover should be responsible for the enobling of the beloved; in both cases Socrates seems to fail (although his charges must bear some responsibility). The result is that the issue of Socrates's corruption of the youth remains ever present and the Symposium can be read as a more nuanced extension of the defence of Socrates in the Apology.

\section{Eryximachus}

One character who deserves detailed treatment is the doctor, Eryximachus. He typically receives bad press and his contribution to the dialogue as a whole is severely underestimated. He is typically treated as a caricature of a medical professional (rather than as an accuarate historical portrayal of a doctor of the period). He is regarded as someone with a limited understanding of the world, who hopelessly tries to extrapolate from his medical training a frame of reference for subjects beyond the scope of his knowledge where he is out of his depth. Such critics argue that he knows nothing about love, but this does not prevent his pedantic pronouncements. Worse than this, he is simply boring; he insists on turning the discussion to medical matters, irrespective of the wishes of the rest of the company.

Such a dismissal of Eryximachus is unfair, inaccurate and fails to appreciate the role which he plays in the discussion. Eryximachus, it is true, has frequent recourse to his medical knowledge, but in this context, he is simply an example of a professional type, a representative of a particular sort of Greek wisdom. Aristophanes never seems to be criticised for behaving like a comic poet because his speech is so entertaining. Similarly Agathon with his polished Greek is a representative of the tragedians. Eryximachus does not bore the company with 
2. Mnesitheus (Athenaeus 11, p. $483 \mathrm{f}=\mathrm{Fr} .45)$; Heraclides of Tarentum Fr. 24; Diocles Fr. 141 Cf. Edelstein, 1945, p. 86 n. 5 3. Heracl. Fr. 45. medical details; rather this knowledge is sought out. His discourse on drunkenness is in response to the complaints of Pausanias, Aristophanes and his host, Agathon, regarding their hangover from the previous night's carousing, and he uses his medical expertise to support the general mood of the gathering at Symp. 176. In any case, ancient doctors frequently wrote on the issue of symposia and drunkenness; the examples of Mnesitheus, Heraclides of Tarentum, Hippocrates and Diocles can be cited in this regard. ${ }^{2}$ Aristophanes requests his help to stop his hiccups at Symp. 185D: 'I look to you, Eryximachus, either to stop my hiccough, or to speak in my stead until I can stop it', and this request contains an example of Plato's playfulness, since the name Erxyimachus literally means 'hiccup-fighter'. Erxyimachus' technical expertise is well-attested in the efficacy of the cure which he suggests. This is reinforced by the presentation of both Eryximachus and his father, Acumenus, as notable physicians at Phaedrus 268A.

Furthermore, the criticism of Eryximachus' extended medical discussion ignores the breadth of his knowledge which also encompasses philosophy and music. Indeed, he discusses music (187A-E) at greater length than medicine (186B-E). (EDELSTEIN, 1945, p. 87) The primary objection one can make against him as a fellow guest is his decision to send away the flute-girl (176E); while supplying further ammunition to those who would make him a bore and a pedant, it reinforces his significance as the instigator of the philosophical discussion. It is Eryximachus who suggests praise of Eros as a suitable subject (176E), though admitting that the idea came from Phaedrus (177A). He is symposiarch, along with Phaedrus, and as such all of the speeches are either addressed to one of them or they are mentioned in the conclusion or one of them is drawn by the speaker into the discussion. (EDELSTEIN, 1945, p. 95) Eryximachus, then, is not simply another speaker, but a major figure in the framework of the dialogue.

Eryximachus is also typically criticised for his dogmatism and his criticism of the speakers who preceded him. This is appropriate to the context and not a feature unique to him. All of the other speakers make some criticism of their rivals, as one would expect in the competitive environment of the symposium. So Pausanias criticises Phaedrus (180C), Aristophanes points out what he perceives as the shortcomings of both Eryximachus and Pausanias (189C), and Agathon (194E) and Socrates (198D) both criticise all of the preceding speakers, although Socrates does this with his usual grace (EDELSTEIN, 1945, p. 88). Indeed, Eryximachus' speech displays greater understanding than the other speeches with the obvious exception of Socrates' discourse. $\mathrm{He}$ is the most philosophical of the other speakers, illustrated by his citation of Heraclitus at 187A: 'The One at variance with itself is drawn together, like harmony of bow or lyre.' ${ }^{3}$ He also mentions the Empedoclean theory of love and strife as responsible for the cohesion of the world: 'Love is not merely an impulse of human souls towards beautiful men, but the attraction of all creatures to a great variety of things, which works in the bodies of all animals and all growths upon the earth, and practically in everything that is; and I have learnt how mighty and wonderful and universal is the sway of this god over all affairs both human and divine (186A). Such references should not be dismissed as pedantic or pretentious; Eryximachus is the only speaker to appreciate the importance of opposing forces in the preservation of the universe. This will be picked up later on by Socrates in his portrayal of Eros as the result of a union of opposites and his discussion of Eros' desire for the opposite.

Eryximachus is also the only speaker aware of Eros' domination of all areas of human endeavour: 'And so not merely is all medicine governed, as I propound it, through the influence of this god, but likewise athletics and agriculture. Music also, as is plain to even the least curious observer, is in the same sort of case (187A).' The importance of his speech is indicated by Socrates' approval: Eryximachus is singled out as one who 'fought well' (193E-194A), whereas the others are treated as a group who have spoken 'sufficiently and well' (177E). Like Phaedrus, he is open to the idea of further instruction: his closing remarks at 188D-E: 'It may well be that with the best will in the world I have omitted many points in the praise I owe to Love; but any gaps which I may have left it is your 
business, Aristophanes, to fill: or if you intend some different manner of glorifying the god, let us hear your eulogy' do not seem to have been taken into account by those who accuse him of dogmatism.

Eryximachus' important role is underscored in other ways. At 223B, only he and Phaedrus are referred to by name as leaving the symposium. He restores order over the banquet when Alcibiades bursts in and threatens to take over and forces him to deliver a speech (214A-C). The weakness of Eryximachus' comments tend to focus on his exaggerated claim that his medical training has given him an elevated insight into the nature of love: 'the master-physician is he who can distinguish between the nobler and the baser Loves, and can effect such alteration that the one passion is replaced by the other; and he will be deemed a good practitioner who is expert in producing Love where it ought to flourish but exists not, and in removing it from where it should not be. Indeed he must be able to make friends and happy lovers of the keenest opponents in the body' (186D). Such comments are best regarded as an ironic persona adopted for the amusement of the company, within the context of a professional's defence of his techn. Agathon does the same and points out that he is following Eryximachus' example.

\section{The Poets}

One of the enlightening pairs of speeches is that of Agathon and Aristophanes, a combination that is masked by the tendency to regard Aristophanes' speech as either a historical portrait or a comic interlude. However, Agathon's speech follows immediately after Aristophanes', a fact which is emphasised by Aristophanes speaking in a position unintended by the original order on account of his hiccups. That both Agathon and Aristophanes should be considered a pairing is further indicated by Socrates' debate with both men on whether the same poet could compose both comedy and tragedy. Socrates, at the end of the Symposium, opposes his own denial that this was possible at Republic Book 3, where one of the main weaknesses of those engaged in imitative arts is that they are unable to cross such genre-boundaries. It makes best sense when interpreted within the context of Diotima's claim that the lover is able to transcend the boundaries of a single science (CORRIGAN \& GLAZOV-CORRIGAN, 2004, p. 185).

The accounts of the lovers, Phaedrus and Pausanias, represent standard encomia of the nature of love within the context of the time. Eryximachus' speech elevates the discussion to a more broadly-based scientific discussion, while Socrates acts as Plato's philosophical spokesman. It is the poets who represent in various ways the primary opposition to Plato's position. Far from being a comic interlude, Aristophanes represents a very real challenge to the Platonic conception of love. While Diotima propounds a view of love in which the lover is able to identify the abstract qualities underlying the beloved and so come to a general love of all individuals with such qualities, Aristophanes represents love as a primal desire for a single beloved which is an inherent part of our nature. Both views are incompatible, but Aristophanes' appears more cogent, since it more closely corresponds to empirical evidence.

Before Agathon's speech is delivered, Plato heightens our expectations regarding the content. Socrates claims to be worried at having to follow the previous speakers, highlighting the increased difficulty he will be in once Agathon has spoken (194A). The framing story has placed Agathon in a central position; dinner at his house becoming an allegory of a philosophical journey. Agathon's speech can be viewed as anticlimactic; many of philosophical assertions which he makes are contradicted during Socrates' elenchus with him.

He represents the weakness of poetry from a Platonic perspective; relying on polished and refined Greek syntax, which merely serves as a mechanism for reciting traditional topoi. When Socrates pulls him up on this, he does at least reply 'very likely I didn't know what I was talking about then, Socrates' (201B9), realising the limitations of his level of knowledge. His account is the sort of thing one would expect from someone too heavily influenced by a sophistic education and falls rather flat after the hype surrounding it. Yet given Agathon's centrality within the dialogue, he cannot be so easily dismissed. His importance is repeatedly underlined by Plato; not 
4. Agathon has 'only' won the Lenaia, although Socrates' claim that he was victorious before 30,000 Greeks, rather than a mor likely figure of 14,000 Athenians, suggests that he has won the Greater Dionysia. cf. Emlyn-Jones, 2004, p. 397. least in Socrates' choosing to recline beside him. His speech might appear anticlimactic to us, but it is the only one of the preliminary speeches to be greated with applause (198A). He is also privileged in the sense that Socrates engages in an elenchus with him. Finally, at the end of the dialogue, he and Aristophanes are the two involved in the new discussion with Socrates concerning whether the same man could compose comedy and tragedy. Agathon not only symbolises the philosophical journey; he provides a fixed point in space and time. Just as his house provides a geographical location for the event, his first victory provides a dramatic date (victory in the Lenaia in 416BC) (EMLYN-JONES, 2004, p. $393)^{4}$. Plato elsewhere only provides the possibility to date the dramatic context so precisely when the dialogue concerns Socrates' trial and its aftermath. (EMLYN-JONES, 2004, p. 393).

While there appears to be much that is wrong with Agathon's speech, such items are concentrated in the opening half of the speech, rather than in the closing segment. Agathon's logic is weak in his categorisation of Love as one of the traditional virtues (196C-D) or in his claim that everyone happily serves Love or indeed in his definition of Love as moderation on account of its mastery of all pleasures (when moderation is self-mastery, not mastery of anything else) (EMLYN-JONES, 2004, p. 395). Conversely, in the second half, Agathon acts as a precursor of Socrates, who later expands on some of his suggestions; such as his comment at 197A that whoever has Love as a teacher enjoys great success and his statement that Love is coveted by those who do not possess him is reflected in Socrates' later contention that desire is for that which one does not have. Agathon plays a major role, since he represents the professional weaknesses of the poets and a sophistic style of education in general. He is not ashamed of his aporia, which he readily concedes without any embarrassment (and there is no suggestion either on his part or amongst his friends that there is anything wrong with this, though perhaps this can be attributed to social decency; it is after all his party). He is primarily concerned with the form and effect of his speech. By this metric, his speech has been a resounding success and he does not seem troubled by the philosophical concessions which he cheerfully makes to Socrates (199D-201C). Socrates too admits that Agathon's words were beautiful (201C). A Socratic education might fail, when students like Alcibiades fail to complete their course of study, but Plato banishes the possibility that a poetic or sophistic education, both of which Agathon represents, can be considered as a serious alternative. In their detachment from the pursuit of philosophical truth and their focus on rousing the emotions of their audience, the poets and sophists lack social responsibility, even if Agathon himself can be forgiven for such excesses. His encomium may have focused more on the effect it had on his listeners than upon argumentation, but he graciously accepts instruction from Socrates.

\section{Socrates and Diotima}

It is time now to turn to the central speech of the dialogue. Socrates' preliminary remarks draw attention to the relationship between narrative form and philosophical content: he praises Agathon for the beauty of his speech, but points out that he has failed in his exposition of love. Socrates then claims that he will expound the truth concerning love, but instead of delivering the encomium which we expect, he describes a lesson which he received on the nature of love from a Mantinean priestess called Diotima. There are numerous advantages to Socrates adopting this tactic. Firstly, it allows him to avoid the crassness of correcting his host, Agathon, at his own dinner-party in celebration of his recent dramatic victory and prevents Socrates from claiming an erotic wisdom of his own, but allows him to speak from a position of knowledge while not compromising his typical claim of ignorance (though erotic matters are one of the few things he claims to know about). Diotima is also differentiated from the other speakers: as a priestess, she speaks with a divinely-sanctioned authority and as a woman she exposes the limited perspective of the earlier speeches which, with the exception of Aristophanes, privilege male homosexual love. It also allows the introduction of the Penia myth, a use of mythology which is not really in character for 
Plato's Socrates. The Penia myth is an example of hyponoia (underthought), the sort of allegory that Plato frequently rejects.

Diotima has impressive qualifications: she delayed the arrival of the plague at Athens by ten years. Despite this, her account of love is perplexing and perhaps disingenuous. By Platonic sleight of hand, she transforms a discussion of eros into an analysis of desire more generally. Even though Socrates endorses her account, there is some subtle criticism of the manner in which she proceeds: at 208C1, she is compared to an accomplished sophist. Her principal claim is that the primary human desire is directed at immortality, but that since this is impossible to attain, it settles at some suitable substitute, such as the production of offspring (206):

Every mortal thing is preserved in this way; not by keeping it exactly the same for ever, like the divine, but by replacing what goes off or is antiquated with something fresh, in the semblance of the original. Through this device, Socrates, a mortal thing partakes of immortality, both in its body and in all other respects; by no other means can it be done. So do not wonder if everything naturally values its own offshoot; since all are beset by this eagerness and this love with a view to immortality (Symp. 208A-B).

This perpetuation of oneself through one's offspring is understandable. As Konstan points out, such offspring can be conceived as having a similar relation to us as younger versions of ourself existing at earlier stages of our lives (KONSTAN, 1998, p. 262). In the case of homosexual males, this desire seems to be directed towards the production of literature as well as the virtue of the beloved, a twofold desire which can be reconciled if one imagines that the object of the literature created is the virtuous upbringing of the boy who is loved. This helps reinforce the importance of the lover as an educator. In both contexts, we shall see, Socrates appears to display shortcomings.

\section{Alcibiades}

While discordant elements have been introduced throughout the course of the dialogue, it is really only with the arrival of Alcibiades that Plato presents us with the key to decode the criticism of Socratic education. Socrates, despite his best efforts, is unable to improve Alcidiades, who claims at Symp. 216:

For he compels me to admit that sorely deficient as I am, I neglect myself while I attend to the affairs of Athens. So I withhold my ears perforce as from the Sirens, and make off as fast as I can, for fear that I should go on sitting beside him till old age was upon me. And there is one experience I have in the presence of this man alone, such as nobody would expect in me - to be made to feel ashamed by anyone; he alone can make me feel it. For he brings home to me that I cannot disown the duty of doing what he bids me, but that as soon as I turn from his company I fall a victim to the favours of the crowd. So I take a runaway's leave of him and flee away; when I see him again I think of these former admissions, and am ashamed. Often I could wish he had vanished from this world; yet again, should this befall, I am sure I should be more distressed than ever; so I cannot tell what to do with the fellow at all.

The weakness of the Socratic system of education is that it can lead one to a realisation of the error of one's ways, but appears incapable of instilling autonomy in the student who has a limited desire to continue his studies. Socrates is an intellectualist: one has only to realise that what one desires is morally wrong in order to correct one's desires, but Alcibiades challenges such a viewpoint. His problem is not a lack of correct belief, but his willingness to yield to his appetites, as well as his recidivism.

Alcibiades's description of his attempt to seduce Socrates famously evokes the Penia myth. Penia would be unable to seduce Poros under normal circumstances, but seizes her opportunity when Poros is inebriated. Similarly Alcibiades detains Socrates after dinner and persuades him to stay the night (217E). There is an inversion, though, as Alcibiades' attempted seduction fails. Socrates is criticised for his failings as a lover, when in reality he behaves in an appropriate manner, rejecting the younger man's advances. This abstinence is described as hubris,
5. E.g. at Crat. 407A; Rep. 378D Phaedr. 229cff. Cf. Corrigan \& Glazov-Corrigan, 2004, p. 123. 
when doing the reverse, i.e. taking advantage of Alcibiades, would deserve this charge. Criticism is also directed at Socrates' apparent detachment from his companions: 'All these possessions he counts as nothing worth, and all of us as nothing, I assure you, he spends his whole life in chaffing and making game of his fellow-men' (Symp. 216E), an accusation hinted at during his military career, when he marches about barefoot on the ice, while the other soldiers complain of the cold, interpreted in some quarters as a mark of disdain for his military companions (220C).

Alcibiades is a further example of the power of love, revealing both his anger against Socrates in his threats of revenge and also admiration in his wish to crown Socrates' 'wonderful head' (213D-E). This love could have been beneficial, since coupled with Socrates' guidance, it led him to approach the study of philosophy: 'Now I have been bitten by a more painful creature, in the most painful way that one can be bitten: in my heart or my soul or whatever one is to call it, I am stricken and stung by his philosophic discourses, which adhere more fiercely than any adder when once they lay hold of a young and not ungifted soul and force it to do or say whatever they will' (Symp. 217E-218A). That even Alcibiades appreciates the importance of love as motivating one to turn to philosophy is illustrated by his subsequent comments at Symp. $218 \mathrm{~A}-\mathrm{B}$, when he names each member of the group as suitable confidants of his erotic account, because they have all had their share of 'philosophic frenzy'.

Alcibiades fails to complete his course of study, illustrating the appeal of the idealised love of the individual recounted in Aristophanes' speech. He chases Socrates, rather than the underlying quality which causes the attraction, wisdom. (In Socrates' case, physical appearance cannot conceivably be advanced as the cause of the attraction). Despite his good intentions, he lacks autonomy: 'take me to Agathon', he cries when he enters, as he is unable to find his way alone to the Good.

This situation is not solely the result of Alcibiades' philotimia. At Rep. VII 538C6-539A3, there is an unusual condemnation of the Socratic elenchus:
Socrates: We hold from childhood certain convictions about just and fine things, we're brought up with them as with our parents, we obey and honour them.

Glaucon: Indeed we do.

Socrates: However, there are other ways of living, opposite to these, possessing pleasures that flatter the soul and attract it to themselves, but which don't persuade sensible people, who continue to honour and obey the conviction of their fathers.

Glaucon: That's right.

Socrates: And then a questioner comes along and asks someone of this sort, 'What is the beautiful?' And, when he answers what he has heard from the traditional lawgiver, the argument refutes him and by refuting him often and in many places shakes him from his convictions, and makes him believe that the beautiful is no more beautiful than ugly, and the same with the just, the good, and the things he honoured most. What do you think his attitude will be then to honouring and obeying his earlier convictions?

Glaucon: Of necessity, he won't honour or obey them in the same way.

Socrates: Then when he no longer honours and obeys those convictions, and can't discover true ones, will he be likely to adopt any other way of life than that which flatters him?

Glaucon: No, he won't.

Socrates: And so, I suppose, from being law-abiding he becomes lawless.

Glaucon: Inevitably. (trans. Reeve)

This illustrates the same sort of problem which confronts the Alcibiades of the Symposium; the Socratic elenchus, despite raising an awareness in him of the error in which he has led his life, is unable to place any check on him. While this seems to be progress of a sort, the Republic passage leads one to 
have doubts. Belief in the traditions of the lawgiver would be preferable, since it provides some curb on immorality. Certainly the accusation that Socrates corrupted the youth lingers in the background, as one might expect in a dialogue which treats of both eros and education. This is a justification of figures such as Apollodorus and Aristodemus, who while they fail to achieve a high degree of philosophical virtue at least have some element of morality, even if provided in the form of mimetic activity.

\section{The end of the banquet}

The failure of the Socratic elenchus to lead one to virtue, if the course of education is not followed to completion, is reinforced by the degeneration at the end of the banquet: '... when suddenly a great crowd of revellers arrived at the door, which they found just opened for someone who was going out. They marched straight into the party and seated themselves: the whole place was in an uproar and, losing all order, they were forced to drink a vast amount of wine' (Symp. 223A-B). This movement from the order of the encomiastic speeches to the typical activity of the symposium (which had been delayed with the banishment of the flute girl) evokes the revellers who destroy philosophy at Rep. 500: 'Think this also, then, namely that an intolerance of the many toward philosophy is by those outsiders who come to philosophy, where they do not belong, like a band of revellers. They are continually abusing each other and being quarrelsome, they invariably make their speeches about men, which is least suited to philosophy.' (Rep. 500B1-6, trans. Corrigan and Glazov-Corrigan).

Alcibiades too was a reveller unsuited to philosophy whose ad hominem remarks concerning Socrates were inappropriate for the forum in which they were delivered. The revellers are like the tyrant and his fellow-revellers in the Republic; they destroy the collaborative nature of the symposium, where the rule had previously been that each guest should drink according to his pleasure and as much as he wanted, whereas they force the guests to drink copious amounts of wine. The revellers are closely linked to Alcibiades, as well as the notion of tyranny; he too bursts into the symposium uninvited and in a drunken state. At Rep. 491B-495B, he is an example of someone who might have become a philosopher-king, but this potential was never actualised because his Socratic-style education was prematurely interrupted.

The second time revellers are mentioned in the Republic is in connecton with the tyrant who with his fellow-revellers is like a parasite on his father's estate $(568 \mathrm{E})$. The revellers of the Symposium are similarly tyrannical in their treatment of the guests. It is no coincidence that the disruption of the revellers reminds one of the earlier disruption of Alcibiades, a man of tyrannical nature, whose attempt to impose his will on the company is only defeated by the moderation of Eryximachus, a further reminder of the manner in which Socrates failed to inculcate virtue in him.

\section{Conclusion}

The Socratic elenchus is not without value. It can convince us of the pointlessness of our current behaviour. But it alone is incapable of leading us towards virtue, a point which Plato makes abundantly clear in the Symposium. The difficulty with Socratic education is not that it is ineffective in making its pupils unaware of their deficiencies, but rather that it forces the student to choose between abstract ideals and political engagement. Alcibiades' failing, as he admits, is due to his philotimia. Not just Alcibiades, but all of the Socratic acolytes of the Symposium, Agathon, Aristodemus, as well as Apollodorus in the framing story, confuse the desire for wisdom with the eros of Socrates. The Symposium is a more nuanced defence of Socrates on the charge of corrupting the youth than that of the Apology. Socrates might have failed Alcibiades, but that is because, as we learn from the Republic, not everyone has the sort of soul that is capable of engaging in philosophy. Furthermore, Alciades must take responsibility for not pursing his course of study to completion. Alcibiades, Agathon, Apollodorus and Aristodemus are convinced by Socrates that their lives are not worth living, but without the insights afforded by philosophical activity, they are 
6. In the case of Admetus, a substitution was required; this does not correspond to the offer made to Orpheus. unable to live a morally correct life in an autonomous fashion, the only sort of life that can be just in a stable manner. The doctrines propounded by Diotima represent a standard of truth (since they are divinely-sanctioned) beyond that possessed by Socrates, but from which those who are only capable of mimetic activity, rather than contemplation of the Forms, are excluded.

A further device used in the dialogue is myth, which pervades the entire structure. Pausanias' speech alerts us to the cynical use to which myth can be put in his criticism of Orpheus' failure to die for Eurydice, whereas Alcestis had died for Admetus. Since the analogy is false, it reminds us that myth can easily be used to mislead. ${ }^{6}$ The main challenge to the philosophical vision of the dialogue, Aristophanes' speech, is presented in the form of an aetiological myth. The philosophical programme is likewise presented in mythic form, with the account of the relationship between Poverty and Resource. We might wish to regard the entire dialogue as a myth; it does after all contain the sort of orality typical of myth: note Apollodorus' frequent 'he said that he said' and emphasis on accuracy, coupled with other more strongly mythical elements, such as the divine revelation experienced by the hero Socrates from his daimonion, and the fantastical characters encountered, even if at a distance. I refer not just to the priestess Diotima, or Poros and Penia, but the strange globular humans described by Aristophanes. A detailed analysis of Plato's use of myth is clearly beyond the scope of this paper. It is worth noting, however, that such myths allow Plato to deliver statements which he would not perhaps wish to commit to and the employment of myth in this manner is an extension of the dialogue form, allowing a complex intertexual web to be developed, even if Plato guides us to what is the correct interpretation.

How are we expected to interpret this criticism of the elenchus or of those who are initiated in the elenchus, but never really understand its purpose? Perhaps the Symposium may be viewed as a defence of Socrates, which is more nuanced than the Apology in pointing out the shortcomings of his educational system, but defending him on charges of corruption. After all, he resists the flirta- tious advances of Agathon and Alcibiades. Socrates proceeds beyond the level of wisdom that can be attained in the elenchus, but the wisdom he receives is represented as being revealed, by the daimonion and by Diotima, not attained through philosophical discussion. Alcibiades mentions the images which he keeps hidden within (216E5-217A2), but images, as we know from the Republic 517D, only consist of second-order wisdom.

The closing of the Symposium is at least somewhat hopeful. Before Socrates leaves he makes sure that his sleeping friends are comfortable (Symp. 223D); if the philosopher is incapable of leading others to virtue, he can still practice it himself by exhibiting a social consciousness. This is similar to Socrates' behaviour at the closing of the Phaedo, where his final words are 'We must sacrifice a cock to Asclepius'. The obvious interpretation is as an offering on his own behalf for being relieved of the agony of hemlock. It is, however, possible to read this as a sacrifice for Plato's speedy recovery from a cold, since illness was the reason alleged for Plato's absence on the last day. The final actions at the banquet and indeed of Socrates' life are other-centred and so the Symposium, even if not a truly robust defence of the Socratic educational system, is a reproach to those who present philosophy as a threat to the ties which bind society together.

\section{BIBLIOGRAPHY}

\section{Ancient Sources}

PLAT0. (1925) Symposium. Ed. \& trans. W. R. M. Lamb. Cambridge, MA, Harvard University Press.

(1930-1935) Republic. Ed. \& trans. P. Shorey. 2 vols. Cambridge, MA, Harvard University Press.

. (1892) The Dialogues of Plato. Ed. \& trans. B. Jowett. 3rd edition. 0xford, 0xford University Press.

\section{Secondary Literature}

BLUNDELL, M. W. (1992). 'Commentary on Reeve', Proceedings of the Boston Area Colloquium in Ancient Philosophy', Vol. 8, p. 144-133.

CLAY, D. (1975). 'The Tragic and Comic Poet of the Symposium', Arion New Series 2, p. 238-261. 
CORRIGAN, K. \& GLAZOV-CORRIGAN, E. (2004). Plato's Dialectic At Play. Argument, Structure and Myth in the Symposium. University Park: The Pennsylvania State University Press.

DOVER, K. J. (1966). 'Aristophanes' Speech in Plato's Symposium', JHS 86, p. 41-50.

EDELSTEIN, L. (1945). 'The Role of Eryximachus in Plato's Symposium', TAPA 26, p. 85-103.

EMLYN-JONES, C. (2004). 'The Dramatic Poet and His Audience: Agathon and Socrates in Plato's "Symposium"', Hermes 132, p. 389-405.

HALPERIN, D. (1986). 'Plato and Erotic Reciprocity', Classical Antiquity 5, p. 60-80.

(1992). 'Plato and the Erotics of Narrativity' in Klagge, J. C. \& N. D. Smith, Methods of Interpreting Plato and His Dialogues. Oxford Studies in Ancient Philosophy Suppl. 0xford, Clarendon Press.

JOHNSON, W. A. (1998). 'Dramatic Frame and Philosophic Idea in Plato', AJP 119, p. 577-598.

KONSTAN, D. (1998). 'Commentary on Rowe: Mortal Love', Proceedings of the Boston Area Colloquium in Ancient Philosophy, Vol. 14, p. 260-267.
MCCABE, M. M. (2009). 'Form and the Platonic Dialogues' in Benson, H. H. (ed.) A Companion to Plato. Malden, Wiley-Blackwell, p. 39-54.

NICHOLS, M. P. (2004). 'Socrates' Contest with the Poets in Plato's Symposium', Political Theory 32, p. 186-206.

NUSSBAUM, M. (1986). The Fragility of Goodness: Luck and Ethics in Greek Tragedy, Comedy and Philosophy. Cambridge, Cambridge University Press.

NYE, A. (1989). 'The Hidden Host: Irigaray and Diotima at Plato's Symposium', Hypatia 3, p. 45-61.

REEVE, C. D. C. (1992). 'Telling the Truth About Love: Plato's Symposium', Proceedings of the Boston Area Colloquium in Ancient Philosophy, Vol. 8, p. 89-114.

RHYS ROBERTS, W. (1900). 'Aristophanes and Agathon', JHS 20, p. 44-56.

ROWE, C. (1998). 'Socrates and Diotima: Eros, Immortality and Creativity', Proceedings of the Boston Area Colloquium in Ancient Philosophy, Vol. 14, pp. 239-259.

SHEFFIELD, F. C. C. (2006). Plato's Symposium: The Ethics of Desire. Oxford, 0xford University Press.

Recebido em fevereiro de 2012. Aprovado em maio de 2012. 